\title{
Utilization of Internet-Based History Learning Media in 21st Century Universities
}

\author{
Pemanfaatan Media Pembelajaran Sejarah Berbasis Internet \\ di Perguruan Tinggi Abad Ke-21
}

\author{
Silvy Mei Pradita (*) \\ Universitas Muhammadiyah Prof. DR. HAMKA \\ Kampus B: Jl. Tanah Merdeka Kp. Rambutan, Pasar Rebo, \\ Jakarta Timur, Indonesia \\ Humar Sidik \\ Universitas Muhammadiyah Prof. DR. HAMKA \\ Kampus B: Jl. Tanah Merdeka Kp. Rambutan, Pasar Rebo, \\ Jakarta Timur, Indonesia
}

\begin{abstract}
In the current postmodern era, the internet has transformed into a cutting-edge weapon in various sectors, ranging from industry, art, economy and others. The internet has always played a vital role in maximizing these various sectors. However, what is the real reality in the world of education? Has the internet been fully utilized? Departing from these worries, this research aims to reveal the real reality of the use of the internet at the tertiary level, especially as a medium for learning history. This research itself uses a descriptive qualitative research method. Data collection techniques used in this study were interviews, observation, and document analysis. The main informants in this interview were two history education lecturers who taught at a public campus in Bandung and two history education lecturers who taught at a private university in the Jakarta area. The interview form used is open and leads to depth of information and is not formal / structured. The goal is to explore the information that is researched further, complete and in-depth. Data analysis in the study took place simultaneously with the data collection process. Among them through data reduction, data presentation, and verification. The results show that in 21 st century learning, the internet has an important role if teachers can maximize its use, because with the internet students are able to dig deeper into existing information, especially now that there are so many historical journal portals that are opened online and accessed for free. Furthermore, the use of the internet can also be applied in a learning system, for example by using blended learning.
\end{abstract}

Keywords: Internet media, 21 st century history learning, history

Abstrak

Di era postmodern saat ini, internet telah menjelma menjadi sebuah senjata mutakhir dalam berbagai sektor, mulai dari industri, seni, ekonomi dan lainnya. Internet selalu memainkan peran vital demi memaksimalkan berbagai sektor tersebut. Namun, bagaimana realita sebenarnya dalam dunia pendidikan? Apakah internet telah dimanfaatkan dengan maksimal? Berangkat dari keresahan tersebut, penelitian ini hadir dengan tujuan mengungkap realitas sebenarnya dari pemanfaatan internet dalam jenjang perguruan tinggi khususnya sebagai media pembelajaran sejarah. Penelitian ini sendiri menggunakan metode penelitian kualitatif deskriptif analitik. Teknik pengumpulan data yang digunakan dalam penelitian ini adalah wawancara, observasi, dan analisis dokumen. Informan utama dalam wawancara ini adalah dua dosen pendidikan sejarah yang mengajar di salah satu kampus negeri di Bandung dan dua dosen pendidikan sejarah yang mengajar di universitas swasta daerah Jakarta. Bentuk wawancara yang digunakan bersifat terbuka dan mengarah pada kedalaman informasi dan tidak formal/terstruktur. Tujuannya untuk menggali informasi yang diteliti lebih jauh, lengkap, dan mendalam. Analisis data dalam penelitian berlangsung bersamaan dengan proses pengumpulan data. Di antaranya melalui reduksi data, penyajian data, dan verifikasi. Hasil penelitian menunjukkan bahwa dalam pembelajaran abad 21, internet memiliki peran penting apabila pengajar dapat memaksimalkan penggunaannya, karena dengan internet mahasiswa mampu menggali lebih dalam informasi yang ada, apalagi dimasa sekarang telah begitu banyak portal jurnal sejarah yang dibuka secara online dan diakses dengan gratis. Lebih jauh lagi, penggunaan internet juga dapat diterapkan dalam sebuah sistem pembelajaran, misalnya dengan menggunakan blended learning.

Kata kunci: Media internet, pembelajaran sejarah abad 21, sejarah 


\section{PENDAHULUAN}

LITERATUS is a journal published by Neolectura, issued two times in one year. Literatus is a scientific publication media in the form of conceptual paper and field research related to social impact and cultural studies. It is hoped that LITERATUS can become a media for academics and researchers to publish their scientific work and become a reference source for the development of science and knowledge.

Our focus: Social and Culture

\section{Our Scope:}

Humanities, Education, Management, History, Economics, Linguistics, Literature, Religion, Politics, Sociology, Anthropology, and others.
Abad ke-21 sering disebut sebagai pengetahuan, yaitu sebuah abad di mana terjadinya sistem transformasi secara besar-besaran ke arah masyarakat berpengetahuan dari masyarakat industri dan agraris (Afandi, Tulus, \& Afriani, 2016). Pada abad ini perubahan terjadi begitu cepat dan sulit untuk diprediksi dari berbagai aspek kehidupan yang ada, maka dari itu masyarakat secara tidak langsung dihadapkan pada berbagai macam tantangan serta dituntut untuk memiliki kualitas yang tinggi dan mapan (Redhana, 2019). Karena dalam abad ini persaingan antar sesama manusia terjadi begitu besar, apalagi dalam ranah dunia maya. Di mana dalam dunia cyber ini setiap orang dari segala penjuru dunia dapat terhubung dan saling bekerja sama sehingga melahirkan berbagai macam profesi baru yang menuntut keahlian lebih tinggi dengan persaingan kelas dunia. Oleh sebab itu abad ke-21 ini menuntut setiap individu untuk membuat berbagai macam terobosan dalam berpikir, menyusun konsep dan melakukan tindakan agar tidak hanyut terbawa gelombang negatif kemajuan teknologi yang berujung pada kegagalan dalam meraih kesuksesan demi mampu bertahan hidup di dunia yang semakin keras ini.

Maka dari itu demi mampu bertahan dalam persaingan tersebut, sistem pendidikan di Indonesia dituntut untuk semakin berkembang ke arah yang lebih maju namun tidak meninggalkan makna yang terkandung di dalamnya. Dengan begitu maka secara tidak langsung tujuan utama dari pembelajaran abad ke-21 adalah membangun kemampuan belajar individu dan mendukung perkembangan mereka dengan cara menanamkan filosofi pembelajaran sepanjang hayat yang aktif dan mandiri. Dengan begitu maka peserta didik akan sadar betapa pentingnya pendidikan dan membuat seorang pengajar juga menjadi lebih mudah membentuk karakter serta mengembangkan keterampilan dalam diri peserta didik. Oleh sebab itu demi mewujudkan hal tersebut peran tenaga pengajar pada abad ke-21 seharusnya bergeser dari pola "penanam pengetahuan", menuju peran sebagai pembimbing, pengarah dan pengukur kemajuan belajar. Teknik pengajaran ini berlaku dalam semua program studi termasuk sejarah.

Sebagai sebuah ilmu yang mempelajari peristiwa masa lampau, sejarah sering kali dianggap remeh, karena hanya berfokus pada hafalan dan berkutat pada masa lampau. Padahal nyatanya di era teknologi saat ini di mana penyebaran informasi begitu cepat lajunya, sejarah memiliki peran penting demi menjaga semangat nasionalisme generasi bangsa. Terdapat sedikitnya dua hal yang perlu diperhatikan dalam pembelajaran sejarah di sekolah maupun Perguruan Tinggi, yaitu menguasai fakta dan mengembangkan kebiasaan berpikir kesejarahan. Melalui pembelajaran sejarah, siswa akan memahami bahwa adanya keterhubungan antara peristiwa masa lalu dengan kehidupan masa kini. Selanjutnya mengembangkan kebiasaan berpikir kesejarahan melalui kajian perbandingan, mahasiswa dapat membandingkan pola yang berbeda pada perjalanan sejarah dari berbagai tradisi dan budaya yang ada di seluruh dunia, sehingga akan memperkaya pengetahuan dan analisis.

Mengacu akan polemik yang ada terkait ilmu sejarah tersebut, maka penelitian ini hadir sebagai sebuah jawaban untuk mengetahui akan pentingnya mempelajari sejarah serta bagaimana sistem pengajaran sejarah di abad 21 saat ini? apakah hanya berputar dengan metode lama atau memaksimalkan teknologi kemajuan zaman, sehingga memungkinkan sejarah berelaborasi dengan metode pembelajaran gaya baru? karena seperti yang telah diketahui bahwa abad 21 ini merupakan suatu era di mana informasi dapat diakses dengan begitu mudahnya dan sejarah identik dengan informasi yang berisi data dan fakta peristiwa masa lampau. Maka dari itu dengan memaksimalkan penggunaan teknologi di abad 21 ini maka akan membuat proses pengumpulan informasi terkait suatu peristiwa sejarah menjadi semakin mudah. Faktor inilah yang lantas menjadi salah satu hal yang menarik untuk dikaji lebih mendalam pada artikel ini karena sifatnya yang seperti pisau bermata dua. Di satu sisi memudahkan seorang sejarawan mencari data yang diperlukan, sedangkan disisi lain membuat orang memandang rendah sejarah karena hanya bermodalkan kemampuan menelusuri informasi di dunia maya.

\section{METODE}

Metode penelitian pada dasarnya merupakan cara ilmiah untuk mendapatkan data dengan tujuan dan kegunaan tertentu. Berdasarkan hal tersebut terdapat empat kata kunci yang perlu diperhatikan yaitu cara ilmiah, data, tujuan dan kegunaan (Sugiyono, 2012). Penelitian ini 
menggunakan metode penelitian deskriptif kualitatif. Bogdan dan Taylor menyatakan bahwa dalam penelitian kualitatif adalah prosedur penelitian yang menghasilkan data deskriptif berupa kata-kata tertulis atau lisan dari orang-orang dan perilaku yang diamati dari fenomena yang terjadi (Moleong, 2013). Sedangkan penelitian deskriptif menekankan pada data berupa kata-kata, gambar, dan bukan angka-angka yang disebabkan oleh adanya penerapan metode kualitatif. Selain itu, semua yang dikumpulkan berkemungkinan menjadi kunci terhadap apa yang sudah diteliti (Moleong, 2013).

Pada Penelitian Kualitatif, Bachri memaparkan bahwa terdapat dua macam validitas penelitian yaitu validitas internal dan validitas eksternal. Validitas internal berkenaan dengan derajat akurasi desain penelitian dengan hasil yang dicapai. Sedangkan validitas eksternal berkenaan dengan derajat akurasi apakah hasil penelitian dapat digeneralisasikan atau diterapkan pada populasi di mana sampel tersebut diambil (Bachri, 2010). Teknik pengumpulan data yang digunakan dalam penelitian ini adalah wawancara, observasi, dan analisis dokumen. Bentuk wawancara yang digunakan bersifat terbuka (open-ended) dan mengarah pada kedalaman informasi dan dilakukan tidak secara formal/terstruktur. Tujuannya adalah menggali informasi yang diteliti secara lebih jauh, lengkap, dan mendalam.

Objek pada penelitian ini adalah dosen di Perguruan Tinggi Jakarta dan Bandung yang mengajar pada program studi pendidikan sejarah sebagai informan utama. Triangulasi adalah teknik pemeriksaan keabsahan data yang memanfaatkan sesuatu yang lain di luar data itu untuk keperluan pengecekan atau sebagai pembanding terhadap data itu. Teknik triangulasi yang paling banyak digunakan ialah pemeriksaan melalui sumber lainnya" (Moleong, 2013). Sebagai triangulasi, peneliti memanfaatkan sepuluh mahasiswa program studi pendidikan sejarah di Perguruan Tinggi yang berada di Jakarta dan Bandung. Penelitian ini berdasarkan alasan bahwa dosen yang mengajar di Perguruan Tinggi tersebut sudah menerapkan sistem pembelajaran yang disesuaikan dengan perkembangan globalisasi saat ini.

Analisis data dalam penelitian berlangsung bersamaan dengan proses pengumpulan data. Di antaranya adalah melalui reduksi data, penyajian data, dan verifikasi. Ketiga tahapan tersebut berlangsung secara simultan atau bersamaan. Analisis data ini digambarkan sebagai berikut:

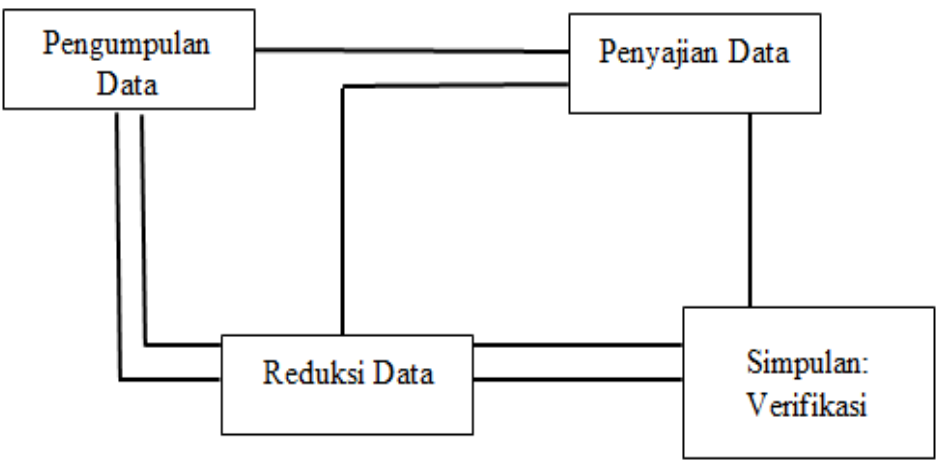

Gambar 1. Proses Analisis Data
Vol. 2, No. 2, October 2020,

pp. 115-122

e-ISSN:

2686-5009

Utilization of

Internet-Based

History

Learning

Media

in 21st Century

Universities

S. M. Pradita

Humar Sidik

\section{Arti Penting Pembelajaran Sejarah}

Sejarah merupakan rekonstruksi peristiwa masa lampau (Kuntowijoyo, 2013). Maka dari itu dengan mempelajarinya akan membuat kita memahami arti penting peristiwa masa lalu dan mengambil hikmah agar dapat dijadikan sebuah pelajaran hidup. Namun kebanyakan individu tidak memahami arti penting dari ilmu sejarah itu sendiri, mereka hanya melihat ilmu sejarah secara sekilas dan memandang sejarah sebagai sebuah ilmu yang kering dan mudah dipelajari karena hanya bermodalkan hafalan semata. Apalagi dengan majunya teknologi zaman sekarang, di mana cukup dengan dukungan internet dan sebuah gadget canggih semua orang dapat mengakses berbagai informasi termasuk sejarah, hal inilah yang lantas membuat sejarah semakin 
dimarginalisasikan sebagai sebuah ilmu di abad 21 sekarang. Padahal secara fakta sejarah tidak semudah itu, demi mendapatkan sebuah informasi yang valid, peristiwa-peristiwa sejarah harus mengalami uji validitas dengan serangkaian metodologinya sendiri. Apalagi di era sekarang informasi hoax bersebaran dimana-mana dalam segala bidang termasuk sejarah, hal inilah yang lantas membuat seorang sejarawan membutuhkan ketelitian yang lebih detail serta analisis cermat dan mendalam ketika mencari berbagai fakta dan data peristiwa sejarah yang ada di internet.

Selain itu jika direnungkan secara mendalam, sejarah sebagai sebuah ilmu memiliki peran yang besar dalam hidup ini, karena dengan sejarah kita dapat menumbuhkan rasa cinta terhadap tanah air dan menjaga identitas bangsa kita (Kartodirdjo, 2017). Seperti yang diketahui pada abad 21 ini informasi dari luar begitu mudah masuk ke dalam bangsa kita dan tanpa disadari berbagai macam informasi yang masuk itu juga turut membawa pengaruh budaya bangsa mereka. Bangsa dari negara dunia pertama hampir keseluruhan memiliki pengaruh yang signifikan terhadap suatu kebudayaan negara dunia ketiga, maka dari itu tanpa filter yang kuat dan pendidikan yang memadai terkait sejarah dan identitas bangsa hanya tinggal menunggu waktu sampai negara dunia ketiga tersebut runtuh dan merelakan budaya mereka lenyap akibat invasi budaya negara dunia pertama. Oleh sebab itu dalam hal ini peran dari pembelajaran sejarah menjadi vital.

Namun tidak serta merta hanya karena peran penting tersebut pandangan para pelajar terhadap sejarah menjadi berubah, dalam hal ini perlu adanya pembenahan terlebih dahulu terkait media dan sistem pembelajaran yang digunakan demi mengoptimalkan pembelajaran sejarah khususnya di perguruan tinggi. Mengapa di perguruan tinggi, karena perguruan tinggi bertugas untuk mencetak generasi masa depan yang siap mengajarkan materi pelajaran sejarah dengan sistem pembelajaran yang lebih canggih dan menarik. Misalnya dengan penggunaan internet. Maksud internet di sini bukan bagaimana cara mengaktifkan internet tetapi lebih ke arah penggunaannya agar lebih bermanfaat. Seperti, mengajarkan bagaimana cara mencari sumber informasi yang valid dan kredibel akan suatu peristiwa sejarah. Memaksimalkan penggunaan aplikasi dan software yang ada seperti Google Classroom dan sebagainya. Dengan penggunaan media yang relevan dengan masa sekarang inilah yang akan membuat pembelajaran sejarah menjadi tidak membosankan.

Maka dari itu dengan adanya pengoptimalan penggunaan sarana dan prasarana berbasis internet di perguruan tinggi maupun sekolah akan memberikan dampak yang positif terhadap pembelajaran sejarah. Apalagi dimasa pandemi Covid-19 saat ini, pengoptimalan media berbasis internet harus dilakukan demi mencegah lahirnya stigma-stigma negatif terhadap pembelajaran sejarah. Inovasi-inovasi baru yang dibentuk atas dasar kreativitas dan imajinasi perlu diperkuat demi melahirkan sistem pembelajaran yang menarik dan beragam, misalnya menggunakan sistem pembelajaran yang berbeda-beda namun tidak memberatkan peserta didik.

Social and Culture

Our Scope: Humanities, Education, Management, History, Economics, Linguistics, Literature, Religion, Politics, Sociology, Anthropology, and others.

\section{Pembelajaran Sejarah di Abad 21}

Abad 21 yang dikenal dengan Knowledge Age (pengetahuan) adalah suatu jaman di mana seorang individu dituntut memiliki kecakapan atau keterampilan, baik hardskill maupun softskill sehingga dapat bersaing dengan negara lain. Hal tersebut juga diungkapkan oleh (Mukhadis, 2013) bahwa dalam saat ini kehidupan manusia dihadapkan pada segala sesuatu yang berbasis pengetahuan dalam segala bidang, seperti dalam pendidikan, pengembangan dan pemberdayaan masyarakat, ekonomi, dan industri. 


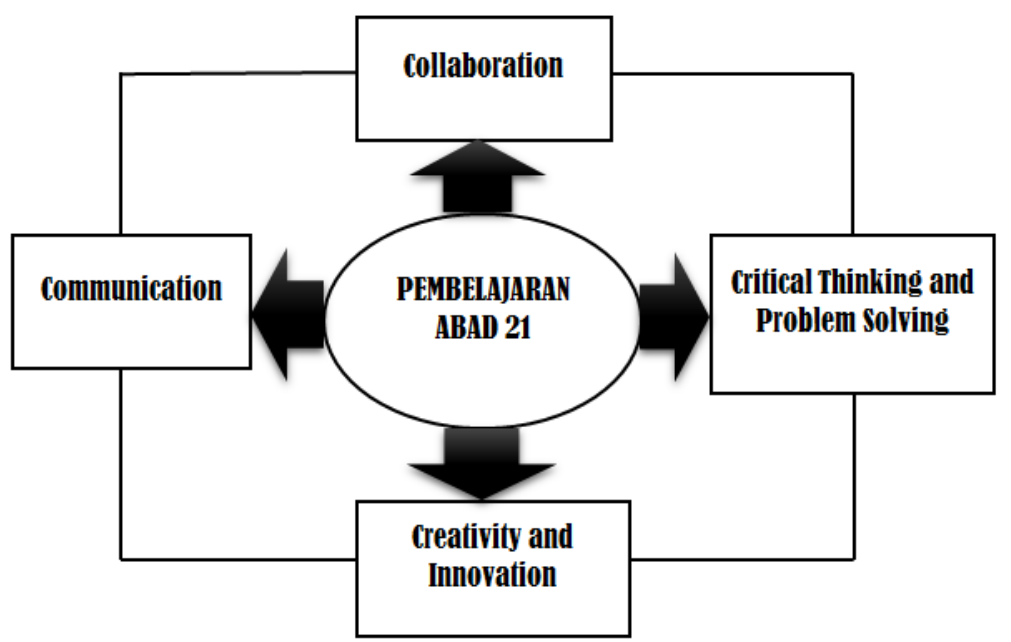

Gambar 2. Pembelajaran Abad 21
Vol. 2, No. 2,

October 2020,

pp. $115-122$

e-ISSN:

2686-5009

Gambar di atas mengemukakan bahwa pembelajaran abad 21 ini mencerminkan empat hal, di antaranya communication, collaboration, critical thinking and problem solving, dan creativity and innovation. Hal ini sejalan dengan hasil wawancara yang dilakukan dengan dosen IY yang mengajar di program studi pendidikan sejarah di Bandung bahwa komunikasi sangat penting pada pembelajaran abad 21 ini karena mahasiswa dituntut untuk aktif di dalam kelas, menggunakan kemampuannya mengutarakan ide-ide, baik pada saat pelaksanaan diskusi kelompok ataupun dalam menyelesaikan tugas-tugas yang diberikan. Menurut IY, pembelajaran abad 21 ini merupakan pembelajaran di era digital. Komunikasi yang dilakukan dapat melewati batas wilayah, bahkan antar Negara bisa dilakukan secara cepat dengan menggunakan perangkat teknologi yang sangat canggih. Dalam hal ini internet sangat membantu mahasiswa dalam berkomunikasi, karena sangat banyak fitur yang disediakan di dalamnya. Melalui hitungan detik saja, mahasiswa bias terhubung ke seluruh dunia dengan hanya menggunakan smartphone.

Lebih lanjut hasil wawancara yang dilakukan pada salah satu dosen SNL di Perguruan Tinggi di Bandung yang mengemukakan bahwa sukses tidak dimaknai sebagai sukses perseorangan atau individu. Oleh karena itu unsur kolaborasi di dalam kelas sangat penting dilakukan pada pembelajaran abad 21 ini. Karena dengan berkolaborasi dan bekerja sama, akan tercipta rasa tanggung jawab dan kepedulian sehingga tujuan bersama dapat dicapai. Hal tersebut sejalan dengan penelitian yang dilakukan di Harvard University bahwa kesuksesan seseorang ditentukan oleh $20 \%$ hardskill dan $80 \%$ softskill. Kolaborasi merupakan gambaran seseorang yang memiliki softskill yang matang.

Menurut Stearns (Kamarga, 2012), manfaat mempelajari sejarah didasarkan pada dua fakta yaitu sejarah membantu memahami manusia dan masyarakatnya, kemudian sejarah membantu memahami perubahan dan bagaimana kondisi masyarakat di masa yang akan datang. Sejarah dapat diibaratkan sebagai "toko informasi" yang berisikan kehidupan manusia dan perilaku masyarakat. Hasil wawancara yang dilakukan pada NFA, dosen di salah satu Universitas di Jakarta bahwa belajar sejarah bukan hanya untuk menghafalkan suatu peristiwanya, melainkan diperlukan pemahaman untuk membangun makna dari peristiwa tersebut. Oleh karena itu dosen NFA memaparkan bahwa menerapkan pembelajaran sejarah yang berbasis internet bisa dengan menggunakan model belajar dengan menggunakan internet sebagai salah satu medianya, atau dengan menggunakan sumber tertulis, salah satunya adalah jurnal-jurnal sebagai sumber belajar.

Lebih lanjut hasil wawancara dengan AM, dosen salah satu universitas di Jakarta, bahwa menerapkan pembelajaran yang berbasis internet di abad 21 ini penting dilakukan, agar mahasiswa bisa mengikuti perkembangan informasi yang semakin maju. Dalam penerapannya, pembelajaran sejarah di kelas bisa menggunakan blanded learning atau pembelajaran campuran antara pembelajaran yang dilakukan secara tatap muka dan secara virtual. Elearning memberikan kesempatan bagi mahasiswa secara mandiri memegang kendali atas keberhasilan belajarnya. Mahasiswa bebas menentukan kapan akan mulai, kapan akan menyelesaikan, dan bagian mana dalam satu modul yang ingin dipelajarinya terlebih dahulu.

Utilization of

Internet-Based

History

Learning

Media

in 21st Century

Universities

S. M. Pradita

Humar Sidik 


\section{Pembahasan}

LITERATUS is a journal published by Neolectura, issued two times in one year. Literatus is a scientific publication media in the form of conceptual paper and field research related to social impact and cultural studies. It is hoped that LITERATUS can become a media for academics and researchers to publish their scientific work and become a reference source for the development of science and knowledge.

Our focus: Social and Culture

\section{Our Scope:} Humanities, Education, Management, History, Economics, Linguistics, Literature, Religion, Politics, Sociology, Anthropology, and others.

\section{Pemanfaatan Pembelajaran Sejarah berbasis Internet di Abad 21}

Perubahan selalu terjadi dalam kehidupan manusia baik di masa lalu, masa sekarang dan masa yang akan datang, hal ini dapat terjadi karena tidak terlepas dari cara berpikir manusia yang bersifat destruktif dan penuh akan rasa ingin tahu. Akibat dari cara berpikir inilah manusia terus berkembang dan menciptakan berbagai macam teknologi yang memudahkannya dalam melakukan setiap pekerjaan (Hasan, 2019). Salah satu bentuk teknologi dimasa sekarang yang memudahkan manusia dalam melakukan setiap pekerjaannya adalah internet. Internet sendiri merupakan sebuah koneksi jaringan yang berguna untuk menghubungkan antar sesama manusia serta berbagai macam informasi yang ada. Dengan pengaruhnya yang begitu besar membuat internet digunakan oleh berbagai sektor dengan tujuan memudahkan sebuah pekerjaan. Ranah pendidikan juga turut menggunakan jasanya demi memaksimalkan hasil pembelajaran di kelas (Isdiyanto, 2005).

Di abad 21 saat ini, internet telah menjadi sebuah kebutuhan bagi setiap orang, terutama mereka yang tinggal di perkotaan. Hal ini secara tidak langsung menunjukkan bahwa hampir setiap manusia mampu mengakses internet dengan baik. Lantas dengan mengacu pada hal tersebutlah maka ranah pendidikan khususnya perguruan tinggi, mencoba untuk menggunakan potensi kemapanan dari internet sebagai media pembelajaran. Salah bidang ilmu yang turut memanfaatkan internet yaitu sejarah.

Seperti yang diketahui, sejarah sebagai salah satu bidang ilmu yang memerlukan banyak data demi mengungkap realitas sebenarnya akan sebuah peristiwa pastinya memerlukan internet baik sedikit maupun banyak demi mencari data-data yang dibutuhkan, karena dimasa sekarang tersedia begitu banyak portal jurnal online baik yang gratis maupun berbayar. Lebih jauh dari ini, seperti yang dikemukakan oleh salah satu informan yakni AM, bahwa dimasa sekarang pembelajaran berbasis internet sangat penting bagi mahasiswa demi menjaga mereka dari ketertinggalan informasi. Karena dengan berbagai kemajuan teknologi dimasa sekarang semakin banyak fakta, teori-teori, dan opini baru yang bermunculan. Maka dari itu dengan adanya internet membuat mahasiswa tidak tertinggal akan info tersebut dan segera mungkin mencoba untuk mendiskusikannya atau menganalisis hal tersebut. Kemudian dengan adanya internet sistem pembelajaran dapat dilakukan secara blended learning, yakni mencampur antara pembelajaran konvensional dan online, demi memudahkan mahasiswa dalam belajar.

Walaupun internet memberikan segala macam kemudahan dalam mengakses informasi namun tetap saja mahasiswa tidak bisa dibiarkan begitu saja. Karena di dalam internet setiap informasi yang ada bercampur antara berita yang terpercaya dan dipenuhi berita hoax. Dalam hal ini penting bagi dosen untuk membimbing mahasiswa tersebut agar mampu memilah dengan baik yang mana informasi yang benar dan mana yang salah. Dengan begitu ketika mahasiswa tersebut telah lulus dan mengajar, ia juga mampu membimbing peserta didiknya dalam memilah informasi. Dengan begini maka tingkat penyebaran berita hoax akan menurun dan membuat generasi muda semakin cerdas. Maka dari itu sebuah sistem pembelajaran berbasis internet yang bertujuan untuk mengumpulkan dan memanfaatkan data yang ada di dalam internet ini akan memicu perkembangan kemampuan analisis, kritik, dan interpretasi yang mereka miliki. Di mana dalam abad 21 saat ini ketiga kemampuan tersebut termasuk kemampuan softskill yang layak dikembangkan karena di era saat ini softskill menjadi senjata utama dalam persaingan global.

Lebih lanjut, selain melalui media pengumpulan informasi, internet juga dapat dimanfaatkan sebagai sebuah sarana untuk melatih kerja sama mahasiswa. Misalnya dengan membuat grup klas melalui media online, seperti WhatsApp atau Google Classroom. Setelah itu dosen memberikan tugas, arahan dan pembagian kelompoknya, lalu melihat seberapa maksimal mereka mampu bekerja sama dalam menyelesaikan tugas yang diberikan. Hal ini bertujuan melatih kemampuan mereka dalam berkolaborasi selain itu dengan cara ini akan menghemat waktu penyampaian tugas di kelas, sehingga waktu dikelas dapat digunakan untuk mengajar dan membimbing peserta didik sepenuhnya. Selain itu dengan cara ini akan membuat peserta didik terbiasa dalam memanfaatkan kecanggihan internet dan apabila terjadi sebuah kendala yang memaksa harus dilakukannya pembelajaran jarak jauh, peserta didik dan dosen telah terbiasa. Misalnya seperti masa pandemi Covid-19 sekarang. 
Maka dari itu dengan pemanfaatan internet sebagai sebuah media pembelajaran akan membuat mahasiswa lebih mudah dalam mengumpulkan berbagai data yang dibutuhkan terkait pembelajaran sejarah. Hal inilah yang lantas kemudian semakin membuka wawasan dalam diri mahasiswa tersebut. Ditambah dengan bimbingan dari dosen, maka akan membuat mahasiswa bersikap lebih bijak lagi dalam menganalisis setiap artikel yang ia temukan, ia akan tahu mana artikel yang memiliki kredibilitas terpercaya dan mana artikel yang dipenuhi narasi hoax yang telah didramatisasi. Kemudian setelah mahasiswa tersebut telah mampu memilih dengan baik artikel yang ada, mereka dituntut untuk lebih kreatif, inovatif dan komunikatif dalam menulis makalah atau artikel agar tidak terkena plagiasi. Karena dengan persebaran informasi yang begitu banyak didunia maya, tanpa adanya pemikiran kreatif yang inovatif dalam merombak dan memodifikasi setiap informasi yang didapatkan akan menyulitkan mereka untuk lolos dari plagiasi. Di sinilah peran internet dalam melatih daya kreativitas, inovasi dan kemampuan mereka dalam mengumpulkan data yang banyak terkait sebuah peristiwa di uji. Namun perlu dipertegas kembali dalam hal ini, demi mampu mendapatkan hasil yang maksimal dari setiap aspek dalam pembelajaran abad 21, seperti communication, collaboration, critical thinking and problem solving, dan creativity and innovation peran dosen sangat penting. Karena jika dosen tersebut tidak mampu membimbing mahasiswa dengan baik akan berujung fatal. Seperti tidak mampu membimbing bagaimana cara memilah informasi yang benar akan sebuah peristiwa sejarah, hal ini akan berujung pada kesalahan mahasiswa tersebut dalam memaknai sebuah peristiwa sejarah yang ada. Akan tetapi jika sang dosen mampu membimbing mahasiswa tersebut dengan baik, niscaya maka pembelajaran sejarah abad 21 dapat mencapai hasil yang maksimal dalam segala aspek yang ada.

\section{PENUTUP}

Pembelajaran berbasis internet di abad 21 ini penting dilakukan terutama di perguruan tinggi, karena berlandaskan pada aspek communication, collaboration, critical thinking and problem solving, dan creativity and innovation. Ada berbagai cara yang digunakan untuk mengoptimalkan empat aspek pembelajaran ini dengan media berbasis internet. Misalnya dengan menggunakan internet sebagai media untuk mencari data terkait peristiwa sejarah. Lebih lanjut dosen juga mengajarkan bagaimana memilah informasi tersebut yang mana kredibel yang mana yang tidak valid. Hal ini secara tidak langsung akan melatih nalar kritis dan kemampuan mahasiswa dalam menyelesaikan sebuah permasalahan. Kemudian dalam tugas penulisan artikel atau makalah dapat dilakukan dengan cara pengecekan plagiasi, hal ini bertujuan untuk menuntut mahasiswa lebih inovatif dan kreatif lagi dalam mengolah data yang didapatkan agar tidak terkena unsur plagiasi, selain itu dalam proses penulisan makalah atau artikel, secara tidak langsung melatih kemampuan komunikasi dalam diri mahasiswa.

Lebih lanjut dalam aspek pembelajaran, internet juga dapat dimanfaatkan sebagai media belajar yang berfungsi melatih kemampuan bekerja sama mahasiswa. Misalnya dengan menerapkan sistem pembelajaran blended learning atau pembelajaran campuran. Dalam hal ini dosen memanfaatkan internet dengan cara mengakses aplikasi yang dapat digunakan untuk membagikan tugas yang akan diberikan. Kemudian waktu yang berada di kelas dimanfaatkan sepenuhnya untuk mengajar dan membimbing mahasiswa. Dengan begitu maka mahasiswa akan lebih intens lagi dalam menjalin interaksi dengan rekan kelompoknya. Walaupun terlihat sederhana beberapa cara yang tertera di atas membutuhkan kerja sama yang baik antara pendidik dan peserta didik. Karena apabila dosen tidak mampu menjadi pembimbing yang baik atau salah dalam mengarahkan mahasiswanya maka akan berujung pada hal yang fatal, seperti kesalahan dalam memaknai sebuah peristiwa sejarah atau gagalnya terpenuhi empat aspek pembelajaran pada abad 21.

\section{DAFTAR PUSTAKA}

Afandi, Tulus, J., \& Afriani, R. (2016). Implementasi Digital-Age Literacy dalam Pendidikan Abad 21 di Indonesia. Prosiding Seminar Nasional Pendidikan Sains (SNPS), 113-120.

Bachri, B. S. (2010). Meyakinkan Validitas Data Melalui Triangulasi pada Pendekatan Kualitatif.
Vol. 2, No. 2, October 2020, pp. $115-122$

e-ISSN:

2686-5009

Utilization of

Internet-Based

History

Learning

Media

in 21st Century

Universities

S. M. Pradita

Humar Sidik 
Jurnal Teknologi Pendidikan, 10(1), 46-62.

LITERATUS is a journal published by Neolectura, issued two times in one year. Literatus is a scientific publication media in the form of conceptual paper and field research related to social impact and cultural studies. It is hoped that LITERATUS can become a media for academics and researchers to publish their scientific work and become a reference source for the development of science and knowledge.

Our focus: Social and Culture

\section{Our Scope:} Humanities, Education, Management, History, Economics, Linguistics, Literature, Religion, Politics, Sociology, Anthropology, and others.

Hasan, S. H. (2019). Pendidikan Sejarah untuk Kehidupan Abad 21. HISTORIA: Jurnal Pendidik Dan Peneliti Sejarah, II(2), 61-72.

Isdiyanto. (2005). Internet sebagai Media Pembelajaran. Jurnal Pengembangan Pendidikan, 2(2), $8-26$.

Kamarga, H. (2012). Pembelajaran Sejarah Berbasis Teknologi Informasi, Perlukah? dalam Pendidikan Sejarah Untuk Manusia dan Kemanusiaan. Jakarta: Bee Media Indonesia.

Kartodirdjo, S. (2017). Pemikiran dan Perkembangan Historiografi Indonesia (kedua). Yogyakarta: Ombak.

Kuntowijoyo. (2013). Pengantar Ilmu Sejarah (Cetakan 1). Yogyakarta: Tiara Wacana.

Moleong, L. J. (2013). Metode Penelitian Kualitatif (Revisi). Bandung: PT Remaja Rosdakarya.

Mukhadis, A. (2013). Sosok Manusia Indonesia Unggul dan Berkarakter Dalam Bidang Teknologi sebagai Tuntutan Hidup di Era Globalisasi. Jurnal Pendidikan Karakter, 3(2), $115-136$.

Redhana, I. W. (2019). Mengembangkan Keterampilan Abad ke-21 dalam Pembelajaran Kimia. Jurnal Inovasi Pendidikan Kimia, 13(1), 2239-2253.

Sugiyono. (2012). Metode Penelitian Kuantitatif Kualitatif dan R\&B. Bandung: Alfabeta. 